\title{
Mapping on Transnational Crime Routes in the New Silk Road: a Case Study of the Greater Mekong Sub-region
}

\author{
Hai Thanh Luong \\ Honorary Principal Research Fellow, School of Global, \\ Urban and Social Studies, R MIT University, Melbourne, Australia \\ haithanh.luong@rmit.edu.au
}

\begin{abstract}
The Greater Mekong Sub-region (GMS), including five Southeast Asian countries and China, has experienced a significant increase in the cultivation of opium, trafficking of heroin and methamphetamine, and consumption of these illicit drugs. In recent years, the GMs has been expanded considerably as supply, destination, and transit route for illegal drug trade's networks to and through, particularly when China officially applied 'Belt and Road' strategy. This paper reviews historical aspects and current trends in drug production and trafficking in the GMS, with special emphasis on Mekong River areas where China is 'located' as the heart of the transition. Some evidence consistent with the 'supply, destination, and transit route' arguments is found through locating and mapping drug trafficking networks to connect with China. Finally, this paper calls for some initial recommendations to improve the process of bilateral and multilateral cooperation in the GMS within the scope of Belt and Road Initiative.
\end{abstract}

\section{Keywords}

Belt and Road Initiative - Greater Mekong Sub-region - drug trafficking - transnational crimes - regional cooperation 


\section{Potential Developments of the Belt and Road Initiative with the Greater Mekong Sub-region}

All six countries' surrounding populations on Mekong River proud of it as the "Danube of the East" with ranking at the eleventh-longest river in Asia and the seventh-longest in the world. The Greater Mekong Sub-region (GMS) shares the water resources of the Mekong River, where covers around 4,350 km length and drains an area of 795,000 $\mathrm{km}^{2}{ }^{1}$. The Mekong River area is a hotspot for various multilateral mechanisms. Two of the most well known are the Greater Mekong Sub-region Economic Cooperation Program (GMS ECP) founded in 1992 involving six countries and the Mekong River Commission (MRC) set up in 1995 between Cambodia, Laos, Thailand, and Vietnam. The GMS, initiated by the Asia Development Bank, focuses on multilateral cooperation in the economic field; while China and Myanmar are not members of the MRC but are involved as dialogue partners. According to the World Bank, the sub-region is growing at a faster pace than the whole of East Asia and the Asia Pacific as the GDP growth rate for 2017 was at 6.4 percent. The population at the sub-region as of 2016 is at 340 million while trading within the region was at US $\$ 444$ billion in $2015^{2}$

As performance-based leading in general viewpoints of powerful chairman in Chinese new century, between September and October of 2013, Chinese President, Xi Jinping delivered intentionally Chinese dreams at his visits at Kazakhstan and Indonesia for the so-called 'Silk Road Economic Belt' and 'Maritime Silk Road of the Twenty-First Century' On land, the Silk Road Economic Belt would mainly target Central Asia and Europe, meanwhile the Maritime Silk Road would primarily focus Southeast, South and North Asia, with China as its hub of the One Belt One Road Initiative (BRI). As one part of the official declaration of the new regime, this strategy was included as the focus of the year's work in the Chinese 'Government Work Report' in 2015 and still occur permanently in the official website of Belt and Road PortalGovernment of China's official channel refer all BRI's activities. The aim of BRI is the economic integration of Eurasia, mainly through investment in infrastructure and transport projects where covers primarily Asia and Europe and includes more than 60 nations, as well as the core connotation of initiative of

1 Summers, Tim. 2008. "China and the Mekong Region." China Perspectives 3:68-77; see also Open Development Mekong. 2019. The Mekong. In Environment and Natural Resources. New York: East-West Management Institute.

2 CARI. 2019. Mekong Monitor. In News \& Views, edited by CARI. Singapore: CIMB ASEAN Research Institute (CARI). 
BRI, is positively developing a cooperative economic partnership with countries along the Belt and Road. ${ }^{3}$ This strategy can also be regarded as a new concept of global collaborative development- "Collaboration, Integration, Cooperation and Substantiality, for building a safe regional and international environment is extraordinarily essential for the implementation of the BRI Strategy. ${ }^{4}$ From 2013 to 2018 the value of trade between China and other BRI countries, including GMs's counterparts, surpassed US $\$ 6$ trillion, accounting for 27.4 percent of China's total trade in goods and growing faster than the country's overall foreign trade, in which only 2018 the value of trade in goods between China and other BRI countries reached US\$1.3 trillion, growing by 16.4 percent year on year . ${ }^{5}$ Trade in services between China and other BRI countries has seen steady progress, growing by 18.4 percent from 2016 to reach US $\$ 97.76$ billion in 2017. According to a report of World Bank (2019), the impact of the BRI on trade have been impacting on at least 71 potentially participating countries; the initiative increases trade flows among participating countries by up to 4.1 percent. $^{6}$

Among of Asia interconnection's network, the GMS is an essential strategic partner in China's BRI. The region serves as a critical link in the realisation of BRI's Maritime Silk Road, which aims to connect China's coast to South Asia, the Middle East and Europe through the South China Sea and Indian Ocean. ${ }^{7}$ The Mekong region is also a critical component for the success of the BRI as it is the mid-point which connects China with the West via ChinaIndochina Peninsula Economic Corridor (CIPEC). Over the past five years or so, CIPEC's progress has been made in infrastructure connectivity and

3 Office of the Leading Group for Promoting the Belt and Road Initiative. 2019. The Belt and Road Initiative Progress, Contributions and Prospects. In Official Document, edited by Belt and Road Portal. Beijing, China: Government of China.

4 Dunford, Michael, and Weidong Liu. 2019. "Chinese Perspectives on the Belt and Road Initiative." Cambridge Journal of Regions, Economy and Society 12 (1):145-167; see also Macaes, Bruno. 2019. Belt and Road: A Chinese World Order. London: Hurst Publishers; and Mendes, Carmen, ed. 2019. China's New Silk Road: An Emerging World Order. Edited by Zheng Yongnian. Vol. 55, China Policy Series. New York: Routledge.

5 Office of the Leading Group for Promoting the Belt and Road Initiative. 2019.

6 World Bank. 2019. Belt and Road Economics: Opportunities and Risks of Transport Corridors. Washington D.C.: World Bank.

7 Dunford, Michael, and Weidong Liu. 2019; see also Brakman, Steven, Peter Frankopan, Harry Garretsen, and Charles van Marrewijk. 2019. "The New Silk Roads: An Introduction to China's Belt and Road Initiative." Cambridge Journal of Regions, Economy and Society 12 (1):3-16; Chan, Man. 2018. "The Belt and Road Initiative-The New Silk Road: A Research Agenda." Journal of Contemporary East Asia Studies 7 (2):104-123. 
construction of cross-border economic cooperation zones through this corridor. ${ }^{8}$ The Kunming-Bangkok Expressway has been completed and operated since 2008 with approximately 1,900 kilometers from Kunming via Xiaomenyang to Jinghong and cross the Lao border at Mohan(Yunnan province) before ending at Bangkok; meanwhile the China-Laos and China-Thailand railways and some other projects are well underway. ${ }^{9}$ Cooperation has also started in building the China-Laos Economic Corridor as well as more intensive efforts have been made to dovetail Thailand's Eastern Economic Corridor and the BRI that made steady advance in economic cooperation between China and Cambodia, Laos, Myanmar, Viet Nam, and Thailand. Positive roles for the China-ASEAN (10+1) cooperation mechanism, Lancang-Mekong cooperation mechanism, and Greater Mekong Sub-region (GMS) Economic Cooperation are becoming more apparent to contribute to the bright future of the region when BRI was expanding. Accordingly, all five countries in GMS accounted for nearly half the size of ASEAN projects supported by BRI in 2018, approximately US $\$ 355.2$ billion out of US $\$ 739$ billion, with the highest total BRI projects in Vietnam (US $\$ 15^{2}$ billion), followed by Cambodia (US $\$ 104$ billion), Laos (US $\$ 48$ billion), Myanmar (US $\$ 27.2$ billion), and Thailand (US $\$ 24$ billion). ${ }^{10}$ The BRI is believed to be motivated by concerns about the slowing domestic growth in China and a desire to enhance its global influence, with the potential to address the global infrastructure gap through supporting low-income countries grow while increasing trade and investor returns. It also has been noted that the BRI will benefit the GMS member countries greatly, especially in infrastructure development, trading, and investment. These countries will acquire greater access to China and other connected markets along the route,

$8 \quad$ Zhuning, Lei. 2019. "China's Connectivity with Mainland ASEAN: The Strategy, Progress and Prospect-With a Focus on Myanmar." In China's Rise in Mainland ASEAN: New Dynamics and Changing Landscape, edited by Chirathivat Suthiphand, Rutchatorn Buddhagarn and Devendrakumar Anupama, 25-64. Singapore: World Scientific; see also Suthiphand, Chirathivat, Rutchatorn Buddhagarn, and Devendrakumar Anupama, eds. 2019. China's Rise in Mainland ASEAN: New Dynamics and Changing Landscape. Singapore: World Scientific.

9 Shahriar, Saleh, Lu Qian, and Sokvibol Kea. 2018. China's Economic Integration with the Greater Mekong Sub-region: An Empirical Analysis a Panel Dynamic Gravity Model. In Economic Discussion Papers, edited by IFW. Kiel, Germany: Kiel Institute for the World Economy (IFW); see also LMC. 2018. "Five-Year Plan of Action on Lancang-Mekong Cooperation (2018-2022)." China Daily, accessed 20 April. http://www.chinadaily.com .cn/a/201801/11/WS5a56cdo4a3102e5b17374295.html.

10 Vineles, Phidel. 2019. Tweaking BRI: What Southeast Asia Can Do. In Commentary, edited by RSIS. Singapore: S.Rajaratnam School of International Studies (RSIS). 
and smaller landlocked countries, in particular, will benefit from inclusive growth. According to the data provided by the Belt and Road State Information Big Data Technologies Co. Ltd under the State Information Center, by the end of 2018, there have been over 670,000 pieces of media reports on the BRIs in China and there have been over 10,000 articles issued per month, in which, among of nine top 'key words' excepted from BRI is not available any key terms relation to either 'non-traditional security' or 'transnational threats' such as illicit trafficking." Noticeably, as rule of 'push and pull,' not all aspects of the BRI are either beneficial values only or without challenges.

\section{Emerging Threats of Transnational Crimes to Belt and Road Initiative at the Greater Mekong Sub-region}

As partly effect of transnational organized crime's threats at Asia and the Pacific region, the GMS has become increasingly as one of the newest concerns of its activities since the past one and half decades. The latest Threat Assessment of the United Nations on Drugs and Crime (UNODC) on Transnational Organized Crime in East Asia and the Pacific estimated that annual organized criminal revenues in East Asia and the Pacific are more than hundreds of US billion from different types of illicit markets. ${ }^{12}$ Of that figure, only illicit methamphetamine accounted for between US $\$ 30.3$ and US $\$ 61.4$ billion; meanwhile trafficking of women and girls for sexual exploitation became a common concern at both regional and international scale. ${ }^{13}$ The rest of these shadow benefits derived from the sale of counterfeits, including counterfeit goods with the total estimate of US\$33.8-US\$35.9 billion; falsified medicines with US $\$ 5^{20}$ million and US $\$ 2.6$ billion. ${ }^{14}$ Additionally, environmental crimes in the Southeast Asia was recorded as the global reach of organized crime, particularly in timber, wildlife, and e-waste. ${ }^{15}$ At the current time, apart from potential contributions in trading, economy, and investment of BRI in the global scales of China's partners, there is still lacking to investigate and analyze the back sides of these program in the field of transnational crimes'

11 Office of the Leading Group for Promoting the Belt and Road Initiative. 2019.

12 UNODC. 2019. Transnational Organized Crime in Southeast Asia: Evolution, Growth, and Impact. Bangkok, Thailand: United Nations on Drugs and Crime (UNODC) Regional Office on Southeast Asia and the Pacific.

13 Ibid.

14 Ibid.

15 Ibid. 
flows. Indeed, both China and the GMs's countries in the initiative will realize enormous economic benefits from the BRI, but it also poses potential risks. Accordingly, though the BRI will provide many new commercial and development opportunities, it has been argued that it may present significant non-traditional security challenges to this region because the countries lack adequate safeguards to prevent cross-border criminal activities. The formation of China's BRI, while promoting the economic development of all countries along the Belt and Road, particularly at GMs's scope, also may create conditions conducive to these activities, such as illegal drug, hum trafficking, wildlife trafficking, migrants smuggling, and money laundering, as well as undermine the usual trade and economic ties between China and other countries with respect to healthy economic development.

Like two sides of one coin, there is a legitimate global economy, but there also is an illegal global economy, namely the first is capital contributions (with globalization's effects), the second is criminal activities (with transnational's results). Globalization refers to the increase in cross-border trade and international capital flows of goods and services that created the free flow and rational configuration of production factors that transcend or eliminate national barriers. ${ }^{16}$ To contrast, however, free movement across trans-borders leads security threats, including transnational criminal operations, particularly under the influence of globalization and regionalization. ${ }^{17}$ As the first inquiry, this paper calls for special attentions on drug trafficking via on land and sea as one of the most pronounced threats to China and the rest of BRI's GMS countries, with following main factors. First, all these irregular forms have been occurring and continuing to threaten regional and national security as well as the social order of each party of BRI. Second, several investing and developing on infrastructure's activities, both land, and sea, across China's network in BRI's nest will also be explored and took advantages of flexible movements in, out, and/or through these countries by traffickers. Finally, in theory, any expending transportation's system is one of the potential risks to transfer illicit goods and immigration's flows when these roads completed.

16 Ohmae, Kenichi. 1999. The Borderless World: Power and Strategy in the Interlinked Economy New York: McKinsey \& Co.; see also Whitaker, Reg. 2002. "The Dark Side of Life: Globalisation and International Crime." In A World of Contradictions, edited by Leo Panitch and Colin Leys, 131-151. Toronto, Canada: Socialist Register.

17 Williams, Phil. 2001. "Transnational Criminal Networks." In Networks and Netwars: The Future of Terror, Crime, and Militancy, edited by John Arquilla and David Ronfeldt, 61-97. Pennsylvania: RAND. 
Known as an opium and heroin production hub since the 1970s, the lawless 950,000 square kilometer Golden Triangle region conceded its notoriety as the global center for manufacturing drugs to Afghanistan in the past two decades. ${ }^{18}$ The drug trafficking and transit routes of the GMS area are proliferating and dynamic, with most drug traffickers changing directions and tactics to exploit any available vulnerable points along the various national and international borders. Needless to say, when most of BRI's project invested and investing in connecting among these countries in the region will also be become as potential targets of traffickers to explore. Indeed, many countries of this region have weak and/or challenging to implement border controls where customs services have to monitor the massive volume of people and vehicles crossing certain land boundaries. Most nations, to a lesser extent of Yunnan province of China, in this region have porous, inaccessible, mountainous areas, some with extensive waterways and coastlines where traffickers took these advantages to transport the illegal drug from this country to others with different modus operandi.

The recent evidence and cases proved that there had been a substantial shift in the drug market in East and Southeast Asia since the latter part of the 2000 s with moving forward methamphetamine. Although the increase in methamphetamine seizures has been significant across the region, it is more pronounced to occur in the GMS. Home to a population of 300 million, the methamphetamine trade there was estimated to be worth over US $\$ 40$ billion a year, for example, in Thailand alone 515 million methamphetamine tablets were seized in 2018-17 times the total amount of the drug took a decade ago. ${ }^{19}$ Opium and heroin production has recently declined with at least a 40 percent decrease in the estimated amount of opium produced in Myanmar from 2013 to 2018, while organized crime have intensified production and trafficking of both low-grade yaba methamphetamine and high purity crystal methamphetamine to alarming levels_-several Mekong countries have already surpassed 2017 seizure totals only a few months into 2018, and Golden Triangle methamphetamine is being seized in high volumes in Australia, Japan, New Zealand,

18 Chin, Ko-Lin. 20o9. The Golden Triangle: Inside Southeast Asia's Drug Trade. New York: Cornell University Press.

19 UNODC. 2019. Synthetic Drugs in East and South-East Asia: Trends and Patterns of Amphetamine-Type Stimulants and New Psychoactive Substances. Vienne, Austria: Global SMART Programme. 
Malaysia, Indonesia. ${ }^{20}$ Meanwhile, heroin still used nationwide in almost countries, particularly in Vietnam always number one, drug users preferred to select methamphetamine as their most favorite, particularly with youth groups in the region. ${ }^{21}$ The shift to synthetic drugs like methamphetamine is particularly difficult for countries to deal because of the complexity of responding to remote and hidden production that can be moved, but also due to the health impacts on drug users in both regional and national scale.

Currently, heroin is almost entirely sourced in Myanmar and distributed for other countries through the number of "trafficking hotspots," including Northeaster Myanmar and Yunnan province (China), across Vietnam's borderland with Northern Laos, the northernmost part of Thailand and the Vietnamese border with Cambodia. In which, the UNODC estimated that China continues to account for the majority of heroin seizures in the GMS region, with annual seizures of 8.5 tons, up from $7 \cdot 3$ tons in 2012. ${ }^{22}$ With regional connectivity initiatives such as the ASEAN Economic Community and GMS Transport Master Plan including infrastructure upgrades and particularly with the noticeable rising of BRI's projects to promote more efficient movement between borders, it is vital that borders are safeguarded from illicit trafficking. Besides that, in terms of methamphetamine, the pharmaceutical industry in China is the second largest in the global at around US $\$ 122.6$ billion and lower than the U.S. with US $\$ 380$ billion in 2016 that has been concerning as one of the most practical risks to connect between meth's producers and precursor chemical's suppliers, particularly across China-Myanmar borderland. ${ }^{23}$ Furthermore, Chinese authorities also admitted there are at least half of dozen laboratories to produce precursor chemicals for the domestic industry could be exploited to smuggle with traffickers for transporting illegal in the

20 Ibid; see also ASEan-narCo. 2019. "ONCB to Drive the 7th Drug Monitoring Network Operational Workshop." ASEAN Narcotics Cooperation Center (ASEAN-NARCO), accessed 12 March. https://aseannarco.oncb.go.th/ewt_news.php?nid=467\&filename=index_EN.

21 Coyne, John. 2019. “Southeast Asia's Looming Drug Crisis Threatens Regional Security." The Strategist, 14 March; see also Coyne, John. 2018. "Drug Production in Laos and Myanmar Still a Major Threat." The Strategist; Broadhurst, Roderic. 2018. Criminal Innovation and Illicit Global Markets: Transnational Crime in Asia. In Organized Crime Research in Australia 2018, edited by Russell Smith. Canberra, Australia: Australian Institute of Criminology.

22 UNODC. 2015. World Drug Report 2015. New York: United Nations on Drugs and Crime, p. 49 .

23 Tan, Huileng. 2018. "China's Pharmaceutical Industry is Poised for Major Growth." CNBC, accessed 20 April. https://www.cnbc.com/2018/04/19/chinas-pharmaceutical-industry-is -poised-for-major-growth.html. 
local and regional market, particularly to Myanmar. ${ }^{24}$ To some extent, China's pharmaceutical industry is characterized by mass production, limited regulation, poor compliance management and inexpensive generic drugs that made China rank at the world's largest chemical producer and exporter. ${ }^{25}$ These non-pharmaceutical companies could supply approximately one-third of the world's chemicals, in which most of these chemicals are legally produced and exported, but limited governance results in the diversion of precursor chemicals into the illicit market along the length of global supply chains. ${ }^{26}$ This large and under-regulated industry base has helped make China the largest supplier of precursor chemicals for the production of illicit synthetic drugs in the GMS region.

In the latest report of synthetic drugs' trends and patterns of UNODC, as a new record, particularly at GMS's countries, in 2017 authorities seized 82 tons of methamphetamine in East and Southeast Asia region. ${ }^{27}$ By the third quarter of 2018, that record had already been surpassed, with seizures totalling 116 tons, in which many vast raids of anti-narcotics enforcement agencies at GMS's are more noticeable. ${ }^{28}$ As a paradoxically, though all GMS's law enforcement agencies (LEAS) have efforted unlimited as these impressive seizures data, there did not correspond change in the purity of methamphetamine at the retail and wholesale levels in the region. The price for methamphetamine across the region has dropped dramatically over the past two years such as in Vietnam, the wholesale price of one kilogram of methamphetamine dropped from US $\$ 13,500$ in 2016 to US $\$ 8,000$ in $2017 .{ }^{29}$ Meanwhile, almost GMS's members such as Myanmar and Thailand had tried to decrease at least $75 \%$ out of the number of clandestine methamphetamine laboratories since 2015, the

24 Laohong, King-Oua. 2015. "R3A Highway a Major Corridor for Drug Gangs." Bangkok Post, accessed 20 April. https://www.bangkokpost.com/thailand/general/666108/r3a-highway -a-major-corridor-for-drug-gangs.; see also Zhuning, Lei. 2019.

25 Coyne, John, and Rebecca Moore. 2018. BRI Could Be a Silk Road for the Drug Trade. In The Strategist, edited by ASPI. Canberra, Australia: Australian Strategic Policy Institute (ASPI); see also Tan, Huileng. 2018.

26 Coyne, John, and Rebecca Moore. 2018; see also Tan, Huileng. 2018.

27 UNODC. 2019. Synthetic Drugs in East and South-East Asia.

28 ASEAN-NARCO. 2019.

29 UNODC. 2019. Synthetic Drugs in East and South-East Asia. 
booming of meth consumption in the region has not yet been controlled. ${ }^{30}$ For example, in the first quarter of 2019, LEAs of Vietnam have investigated 6,552 drug-related crimes and seized more than six tons of illegal drugs-more than the number of cases and quantities captured in all of 2018. ${ }^{31}$ In recent data of LEAS shown that many в R I's infrastructure priorities investing, both railway and highway, to connect among GMS countries have been explored by traffickers.

\subsection{Routes on the Land}

In China, the area of northern Myanmar's borderland with southern China (Yunnan province) remains the primary source of heroin in the Chinese market. ${ }^{32}$ Accordingly, the trafficking between Myanmar and China flows in both directions, as the processing of heroin requires precursor chemicals, particularly acetic anhydride. ${ }^{33}$ The majority is trafficked from Myanmar directly across the border to Yunnan province (China), which has become a critical trans-shipment route for the regional market and beyond. ${ }^{34}$ Besides, drugs from Myanmar transit to southern China including the provinces of Guangxi, Guangzhou, and Fujian, and onwards to south-eastern coastal areas, as one of the most traditional and preferred drug trafficking routes, by various overland methods. ${ }^{35}$ In fact, after the vigorous crackdown drug trafficking activities of the Thai army and police in the early 2000 s (particularly across Thailand's borderland with Myanmar), traffickers were forced to use new journey for delivering methamphetamine; while Yaa baa (heroin in local Thai language) began to entering Thailand from Laos through transporting by land via border

30 ASEAN-NARCO. 2018. ASEAN Drug Monitoring Report 2017. Bangkok, Thailand: ASEAN Narcotics Cooperation Center (ASEAN-NARCO).

31 Hai, Thanh Luong. 2019. "Vietnam and the Mekong's Synthetic Drug Epidemic." The Diplomat.

32 UnODC. 2015; see also Zhang, Sheldon, and Ko-lin Chin. 2015. The Chinese Heroin Trade: Cross-Border Drug Trafficking in Southeast Asia and Beyond. New York: New York University Press; Ministry of Public Security of China. 2014. Annual Report on Drug Control in China 2005-2013. Beijing, China: National Narcotics Control Commission (NNCC).

Zhang, Sheldon, and Ko-lin Chin. 2015; see also Su, Xiaobo. 2013. 'China’s Antidrug Policies in Southeast Asia' Golden Triangle. In Asia-Pacific Bulletin, edited by Satu Limaye. Hawaii: The East-West Centre.

34 Zhang, Sheldon, and Ko-lin Chin. 2015; see also Chin, Ko-Lin. 2009.

35 INCSR. 2014. International Narcotics Control Strategy Report Washington D.C.: United States Department of State, Bureau for International Narcotics and Law Enforcement Affairs; see also UnODC. 2011. Partnership against Transnational Crime through Regional Organized Law Enforcement (PATROL): Baseline Survey and Training Needs Assessment in Myanmar. Bangkok, Thailand. 
towns, including Chiang Khong, Nan, Loei, Nong Khai, Mukhdahan, Nakhon Phanom, and Ubon Ratchathni. ${ }^{36}$

The BRI consists of six focused economic corridors, including a ChinaIndochina corridor crossing Myanmar, Laos, Vietnam and Malaysia and ending in Thailand, and a Bangladesh-China-India-Myanmar corridor. Some of them, such as the China-Indochina corridor, overlap with established economic routes in the GMS since 1992. That means that they also overlap with established trafficking routes and transit hubs-demonstrated by the clear picture in the recent reports of the UNODC. ${ }^{37}$ Although in areas where the BRI corridors and the GMS routes don't connect, new transportation infrastructure will link the Chinese markets with new trading partners. It may also link one of the world's primary sources of precursor chemicals with new markets and beyond through GMS region. Besides that, the BRI also extends west towards Europe, through the China-Central Asia-West Asia Economic Corridor, linking China to its western neighbors. While there have been limited methamphetamine investigations and seizures in the Central Asia countries to date, the BRI's initiative to connect them could in time provide the necessary infrastructure to access new markets in Kyrgyzstan, Uzbekistan, Tajikistan and Kazakhstan. ${ }^{38}$ However, it could also open new fast, and secure trafficking routes to the highly profitable European markets.

All these transportation's milestones have been detecting some drug trafficking cases by LEAs in recent years that could lead to these routes to become as potential targets of traffickers for shipping illegal drugs from domestic to GMS region and beyond of BRI's network. Firstly, the China-Myanmar Economic Corridor (CMEC), which is an estimated 1,700-kilometre-long corridor that will connect Kunming, the capital of China's Yunnan Province, to Myanmar's major economic hubs-first to Mandalay in central Myanmar, and then to Yangon and to the Kyaukphyu Special Economic Zone (SEZ) in Rakhine Stateto "increase opportunities for illicit profiteering." 39 Alongside

36 Wancheng, Zhan, and Li Chang. 2016. "Law Enforcement and Security Cooperation in the Mekong River Basin: Demands, Conditions, and Visions." Proceedings of International Symposium on Policing Diplomacy and the Belt \& Road Initiative, Hangzhou, China, 28-30 June; see also Windle, James. 2015. Drugs and Drug Policy in Thailand. In Improving Global Drug Policy: Comparative Perspectives and UNGASS 2016, edited by Foreign Policy at Brookings. Washington D.C.: Brookings.

37 UNODC. 2019. Synthetic Drugs in East and South-East Asia.

38 Coyne, John, and Rebecca Moore. 2018. BRI Could Be a Silk Road for the Drug Trade. In The Strategist, edited by ASPI. Canberra, Australia: Australian Strategic Policy Institute (ASPI).

39 International Crisis Group. 2019. Fire and Ice: Conflict and Drugs in Myanmar's Shan State. Brussels, Belgium: International Crisis Group. 
with highway's side, the Dali-Muse-Lashio Railway were also targeted by smugglers to ship illegal drugs between Myanmar and China. ${ }^{40}$ Besides that, secondly, although CIPEC initiative helped to ease travel for tourists wanting to explore regional cultures and commerce traders seeking new chances in GMS's neighboring countries, many transport roads in this corridor have been continuing to investigate to transport illicit drugs. ${ }^{41}$ In particular, the R3A Highway, running 1,861 kilometres from Chiang Rai's Chiang Khong district in Thailand to the city of Kunming in Yunnan province in Southwestern China via Laos, was inadvertently making it more adaptable for drug trafficking networks to smuggle their heroin and methamphetamine products in, out, and/or through all GMS countries via Mekong River. In fact, though many traffickers can ship drugs by transfer along this trans-national river, almost them preferred to select land's routes with more convenient forms to transporting via the R3A Highway, which opened in 2011 to link Thailand to China through Myanmar and Laos. ${ }^{42}$ Both precursors and drug products are often concealed within increasing large licit trade flow across the region, spurred by more excellent connectivity and improved transport infrastructure from these BR Is. ${ }^{43}$ Furthermore, a combination of high-level corruption and the existence of safe havens controlled by army-backed militias or non-state armed groups, which allow industrial-scale synthesis of drugs and their trafficking in ton's quantities via these routes, that is one of the main reasons to lead weak border control and of course, trafficker often take advantages of these conditions to transport heroin and meth. ${ }^{44}$ Thirdly, the rest of GMs's countries in BRI are covering a number of China's investment-based projects that also face to potential risks of the balloon effect of drug trafficking's flows in the region, particularly across three

$40 \quad$ Ibid.; see also Zhuning, Lei. 2019.

41 Reuters. 2018. "Myanmar Scales Back Chinese-Backed Port Project Over Debt Fears." The Guardian, accessed 20 April. https://www.theguardian.com/world/2018/aug/o2/myanmar -scales-back-chinese-backed-port-project-over-debt-fears.; see also Tobin, Meaghan. 2019. "What Does China's Belt and Road Have to Do with Myanmar's Meth Problem?". South China Morning Post accessed 20 April. https://www.scmp.com/week-asia/geopolitics /article/2181223/what-does-chinas-belt-and-road-have-do-myanmars-meth-problem.; Grafilo, John. 2019. "Shan a Global Production Hub for Illegal Drugs, Say Security Think Tank." Myanmar Times, accessed 20 April. https://www.mmtimes.com/news/shan-global -production-hub-illegal-drugs-says-security-think-tank.html.

Cachia, Renaud, and Thura Lwin. 2019. Methamphetamine Use in Myanma, Thailand and Southern China: Assessing Practices, Reducing Harms. In Drug Policy Briefing edited by TNI. Amsterdam, the Netherlands: Transnational Institute (TNI); see also Laohong, King-Oua. 2015.

43 Windle, James. 2015.

44 International Crisis Group. 2019. 
projects among Cambodia-Laos-Thailand-Vietnam. There includes in the Lao PDR, these are the upgrading of National Road No. $2\left(\mathrm{AH}_{13}\right)$ and National Road No. 8 (AH15) on the Asian Highway Network, a system of roads linking Asia and Europe; in Viet Nam, these are Southern Coastal Corridor Project (Phase 2) and Ho Chi Minh City-Moc Bai Expressway; and in Cambodia and Thailand have one road projects each - the upgrading of Siem Reap to Rattanakkiri National Roads and Hat Yai-Sadao Motorway. While three projects supported cross-border trading in the sub-region, there have been detected many transnational drug trafficking cases on these transportation's roads in recent times. ${ }^{45}$

\subsection{Routes via the Sea/River}

On the sea and rivers, except for some traffic through ports in the southern zone of Myanmar to south Thailand, Malaysia, and Indonesia, most transfers in the GMS go via the Mekong River. For sea routes, at the current time, there are two main concerns at two main ports of Myanmar and Cambodia with supported and invested by BRIs projects. First one is the Kyaukpyu port, which is an entry point for a $480-$ mile $(770 \mathrm{~km})$ pipeline delivering oil and natural gas to China's Yunnan province. It was considered as a critical part of BRI to not only give China an alternative route for energy imports from the Middle East that avoids the strategic chokepoint of the Malacca Strait but also expand trade links across the world, the concern of insecurity from drug lords to explore this new routes to ship illicit drugs that could face in the future. ${ }^{46}$ Under the original plan, with the initial US $\$ 7.3$ billion investment, the Kyaukpyu deepwater port would have had a container capacity to rival that of ports such as Manila or Valencia in Spain. ${ }^{47}$ While Beijing says BRI is always mutually beneficial for it and its partners, questions national security and social order, particularly with threats of drug trafficking activities, are often lighter focusing rather than trading and investing from these projects. The second one is the Preah Sihanouk Autonomous Port in Sihanoukville City, a Cambodia's deep-water port, that is one part of a vital trade route for President Xi Jinping's BRI. In fact, unlike neighboring countries Thailand, Myanmar and Vietnam, has ensured Cambodia is at the core of belt and road plans in southeast Asia, where between 2013 and 2017, China invested US $\$ 5.3$ billion in the countrythat's more money than the Cambodian government did, the city has become

\footnotetext{
45 ASEAN-NARCO. 2018.

46 Reuters. 2018.

47 Ibid.
} 
a focal point for Chinese investment. ${ }^{48}$ Beyond Sihanoukville, belt and road money are financing a new four-lane highway to Phnom Penh and a bigger airport in the capital. While not directly funded by Belt and Road money, the casinos and condo complexes are a by-product of a city that has given itself over entirely to Chinese investment that calling for concerns from financial crime, money laundering, and drug trafficking. ${ }^{49}$ For river routes, while the BRI runs more than 60 countries in the region, most illicit drugs cases only occur on the Mekong River. Almost cases, traffickers used speedboats to ship drugs along the Mekong River, particularly in Nakhon Phanom-one of Thailand's poorest border province in the northeast, as one of the prioritized routes. ${ }^{50}$

Although the current paper focuses on GMs's spheres on the progress of BRI, other practical connects to China via this region could not ignore. Notably, in the borderless of BRI schemes between GMS and its closed neighbors across China-Pakistan Economic Corridor (CPEC), drug trafficking is difficult to identify where the first nodes and the final destinations that request to put together these hot spots into the scope of GMs's transport hub of illicit. Since heroin from Myanmar was no longer sufficient to meet regional demand, large volumes were imported from Afghanistan to China via Pakistan through connecting at Gwadar port, where drug shipments were transported by sea through a variety of transit countries with more complicated journeys. ${ }^{51}$ Besides, Chinese criminals, Latin American cartels and Nigerian brokers have been forging ties and widening their international networks to transport amounts of cocaine from Latin America via shipping containers or through drug mules to come the GMS's regional demand. ${ }^{52}$

48 Ellis-Peterson, Hannah. 2018. "No Cambodian Left': How Chinese Money Is Changing Sihanoukville." The Guardian, accessed 20 April. https://www.theguardian.com/cities /2018/jul/31/no-cambodia-left-chinese-money-changing-sihanoukville.

49 Ibid.

50 AFP. 2019. "Drones, Boats and Megabaht: Laos Route Spews Meth into Thailand." Bangkok Post, accessed 20 June. https://www.bangkokpost.com/world/1693200/drones -boats-and-megabaht-laos-route-spews-meth-into-thailand.; see also Natanri, Chakkrapan. 2017. "Bioom in Heroin Seized After Clash near Mekong." Bangkok Post. Accessed 20 April 2019. https://www.bangkokpost.com/thailand/general/1370595/b1oom-heroin -seized-following-clash-near-mekong-river.

51 Chang, Yen-Chiang, and Mehran Khan. 2019. "China-Pakistan Economic Corridor and Maritime Security Collaboration: A Growing Bilateral Interests." Maritime Business Review $4(2): 217-235$.

52 Carvalho, Raquel, and Marcelo Duhalde. 2018. "Narcos: The Hidden Drug Highways Linking Asia and Latin America." South China Morning Post, accessed 20 April. https:// multimedia.scmp.com/week-asia/article/2174634/narcos-hidden-drug-trafficking/. 
Currently, nobody can neglect about insurgents of drug trading in the GMS, which are making enormous profits from their operations with numerous incomes per year for trafficking heroin and meth. Indeed, the lucrative nature of the illicit drug trade highlights the significant resources that transnational criminals have at their disposal to offend with impunity. This highlights the difficult challenge in combatting these crimes and indicates the urgent requirement for regional cooperation to combat drug trafficking among the GMS countries, despite the actions of the governments of Southeast Asia and China to enhance narcotics control trade since the 1990s and still expand in the progress of BRI since 2010s. Although no any data can update continuously and precisely the number of traffickers is arrested each year for trafficking illicit narcotics in GMS, the high profits of the drug trade continue to lure thousands more into the business. All these features made Mekong areas to become as one of the main trafficking routes in the region and even, expanding to other countries via connection's network transportation system on the BRI's project.

On 25 February 2019, the government of Thailand and the UNODC initiated a strategic partnership with focusing on GMs's concerns, which is not only to advance border management under Thailand's ASEAN 2019 Chairmanship but also to develop a 'roadmap' to consolidate steps the region can consider improving border policies, investments, and operational capacities in support of regional political security and economic agendas. Combining with Chinafounder of BRI, all five countries in GMS need at least to consider four issues in light of the UNODC's latest report and Thailand's efforts, and also Vietnam's in the next ASEAN Chairmanship in 2020, to improve regional border control and prevent drug trafficking.

First, as an ASEAN dialogue partner and a leadership GMS member, China should offer material support, including access to subject-matter expertise, to Thailand and the UNODC for the development of the border management roadmap. Door-to-door exchanging and discussing on a comprehensive framework and specific measures to ensure security across borders among parties on the BRI's projects that should be prioritized. Second, Beijing should also examine opportunities to support the enhancement of existing border initiatives along the Thai-Myanmar, Thai-Laos, and Cambodia-Laos-Vietnam. One program that has shown promise is the BLO network. Third, LEA's authorities in China should consult and advise their government to enhance investment and budget for supporting all BRI's neighboured systems in GMS in patrolling and controlling drug trafficking's activities on both land and sea. The model of Mekong River Patrol, which China subsidized annually US\$50,000 via UNODC 
regional office, should also be copied and applied on the land via establishing and joining joint investigation team to combat illegal drug trading. Finally, China should look to expand its law enforcement and border security capacity development efforts in Laos and Myanmar, where are still lacking professional approaches in deploying effective measures to prevent and combat drug trafficking activities at the current time.

The UNODC's latest report in March and June 2019 provided the most unequivocal evidence to date that the region is facing a methamphetamine crisis. Without new strategies and multilateral efforts among GMS countries, the problem will increase and even, difficult to control. The regional drug crisis provides an opportunity for China to work with ASEAN authorities in the Mekong region to strengthen border controls that could disrupt illicit drug supply chains. This practical cooperation and active collaboration could also be contributed to ensuring the 'main' aims of BRI-trading, economy, and investment, to come in its primary means in the future. 